\title{
Gum Arabic as novel anti-oxidant agent in sickle cell anemia, phase II trial
}

\author{
Lamis Kaddam ${ }^{1 *}$ (D), Imad Fadl-Elmula ${ }^{2}$, Omer Ali Eisawi ${ }^{3}$, Haydar Awad Abdelrazig ${ }^{4}$, \\ Mohammed Abdelraman Salih ${ }^{5}$, Florian Lang ${ }^{6}$ and Amal M. Saeed ${ }^{7}$
}

\begin{abstract}
Background: Sickle cell anemia patients suffer from oxidative stress due to chronic inflammation and self-oxidation of sickle hemoglobin ( $\mathrm{Hb} \mathrm{S}$ ). Chronic oxidative stress contributes to endothelial dysfunction, inflammation and multiple organ damage in sickle cell disease (SCD). Thus, antioxidant medication may favorably influence the disease. Gum Arabic (GA), edible, dried, gummy exudates from Acacia Senegal tree, has been claimed to act as an anti-oxidant and cytoprotective agent, protecting against experimental hepatic, renal and cardiac toxicities in rats. We hypothesized that regular intake of GA increases anti-oxidant capacity and reduce oxidative stress.
\end{abstract}

Methods: Forty-seven patients (5-42 years) carrying hemoglobin SS were recruited. Patients received $30 \mathrm{~g} /$ day GA for 12 weeks. Total anti-oxidant capacity $(T A C)$, malondialdehyde (MDA) and hydrogen peroxide $\left(\mathrm{H}_{2} \mathrm{O}_{2}\right)$ levels were measured by spectrophotometric methods before and after GA intake. Complete blood count was measured by sysmex.

Results: Gum Arabic significantly increased TAC level $P<0.001$ and decreased the oxidative markers MDA $(P<0.05)$ and $\mathrm{H}_{2} \mathrm{O}_{2}(P<0.005)$.

Conclusions: GA has potent anti- oxidative properties in sickle cell anemia. The anti-oxidant effect of GA may thus favorably influence the clinical condition of this and further diseases characterized by oxidative stress.

Trial registration: ClinicalTrials.gov Identifier: NCT02467257. Registered 3rd June 2015. Retrospective registration.

Keywords: Gum Arabic, Sickle, Anti-oxidant, Oxidative stress

\section{Background}

Chronic inflammation with oxidative stress emerged as an important pathogenic mechanism in sickle cell disease (SCD) [1-3]. SCD is primarily a disorder of RBCs, which are a significant source of free radicals in biological systems [4]. Oxidative stress may thus contribute to the abnormalities that underlie the clinical course of SCD [4]. Oxidative stress is one of the factors that modulate the phenotypic expression of SCD [5]. Oxygen has the ability to form highly reactive metabolites such as superoxide anion radical $\left(\mathrm{O}_{2}{ }^{-2}\right)$, hydrogen peroxide $\left(\mathrm{H}_{2} \mathrm{O}_{2}\right)$, and hydroxyl radical $(\cdot \mathrm{OH})$. These reduced metabolites of oxygen are referred to as "reactive oxygen species ROS" [6]. Oxidative stress can damage specific molecular targets (lipids, proteins, carbohydrates etc.),

\footnotetext{
* Correspondence: lamiskaddam@hotmail.com

${ }^{1}$ Department of Physiology, Faculty of Medicine, Alneelain University, P.O.

Box: 11121, Khartoum 12702, Sudan

Full list of author information is available at the end of the article
}

resulting in cell dysfunction and/or death. Oxidative stress level increases during vaso-occlusive crises and acute chest pain [7]. Oxidative stress is not only linked to chronic inflammation, it also contributes to endothelial dysfunction [8].

Sickle cell anemia patients have high levels of oxidative stress markers and low levels of antioxidant capacity. In addition to oxidative stress SCD patients have lower plasma levels of the antioxidant vitamins (A, C and $\mathrm{E}$ ), lower serum levels of zinc and significantly higher serum levels of copper in comparison to controls $[9,10]$. Zinc deficiency with a copper excess may contribute to free radical production and oxidative damage [9]. Deficiency of antioxidant vitamins (A, C and E) could account for some of the observed manifestations of SCD such as increased susceptibility to infection and hemolysis [11]. Any medication that increases the antioxidant capacity is thus expected to favorably influence the clinical course of the disease. Gum Arabic (GA) is an edible, dried, 
gummy exudate from the stems and branches of Acacia Senegal and Acacia Seyal. Oral intake of GA has been shown to provide several health benefits [12], such as prebiotic effects [13]. GA significantly increases Bifidobacteria, Lactobacteria, and Bacteriodes in the gut [13]. GA is claimed to have anti-cancer [13], anti-malarial [14] and immune-modulatory effects [14, 15]. GA is considered to act as an anti-oxidant and cytoprotective agent [16] and it can protect against experimental hepatic, renal and cardiac toxicities in rats [19]. GA is assumed to be effective mainly due to strong anti-oxidant properties [17, 20,21]; GA may enhance the activity of superoxide dismutase (SOD) in kidney [22]. Amino acids tyrosine, histidine and methionine seem to be responsible for the antioxidant capacity of GA against ROS [23]. In experimental chronic renal failure (CRF) in rats GA administration decreased the superoxide production to control levels and raised the level of GSH and TAC. Alyahia et al. revealed that GA offers protection against cyclophosphamide-induced urinary bladder cytotoxicity in a rat model by neutralizing ROS and mitigating oxidative stress [16]. GA was effective as a potent superoxide scavenger in doxorubicin induced cardiotoxicity murine model [24]. Moreover, GA was found to decrease MDA renal level on Cisplatin-Induced nephrotoxicity rat model [25].

These observations suggest that GA may find clinical application in a variety of conditions where cellular damage is a consequence of oxidative stress like sickle cell anemia. We hypothesized that regular intake of GA would increase the TAC and decrease the oxidative stress markers. The present study tested whether Gum Arabic may have anti-oxidant properties in SCA patients.

To the best of our knowledge this is the first study conducted to investigate the effect of oral administration of GA on anti-oxidant capacity in sickle cell anemia patients.

\section{Methods}

The participants of this study were recruited from the out patients clinic of pediatric and adult hematology units in Military Hospital-Khartoum-Sudan. The Inclusion criteria were: patients homozygous for SCD (SS) as documented by Hemoglobin electrophoreses. Their age ranged between 5 and 50 years. The total number of participants recruited was 47 . All medications and dosages had been stable for 2 weeks before study entry. Exclusion criteria: patients receiving blood transfusion within the last three months or admitted to the hospital within 2 weeks because of SCD-related events or crisis.

\section{Gum Arabic administration}

GA in powder form is a $100 \%$ natural extract powder produced mechanically from the wildly grown Acacia
Senegal tree with a particle size less than $210 \mu \mathrm{m}$. GA in powder form was provided from Dar Savanna Ltd., Khartoum, Sudan. Properties and composition of GA are listed elsewhere [26]. The daily dose was $30 \mathrm{~g}$, given in one sachet to be consumed early morning dissolved in water for 12 weeks. The GA was provided to the participants every two weeks for three months (14 sachets per each visit). Empty sachets were retained every visit as indicator of compliance.

\section{Sample collection and colorimetric determination of TAC and oxidative markers}

Blood sample was collected before administering GA and after 12 weeks as follows:

Two ml in EDTA container and two $\mathrm{ml}$ in plain container. The serum and plasma was separated by centrifugation at $3000 \mathrm{rpm}$ for $15 \mathrm{~min}$ then aliquot into four eppendorf tubes and stored at $-85{ }^{\circ} \mathrm{C}$ till final analysis. All blood samples were collected by certified nurses in Military Hospital.

Antioxidant capacity in the serum was determined by the reaction of antioxidants in the sample with a defined amount of exogenously added hydrogen peroxide $\left(\mathrm{H}_{2} \mathrm{O}_{2}\right)$. The antioxidants in the sample eliminated a certain amount of the provided hydrogen peroxide. The residual $\mathrm{H}_{2} \mathrm{O}_{2}$ was determined calorimetrically by an enzymatic reaction which included the conversion of 3,5 ,dichloro -2- hydroxybenzene sulfonate to a colored product [27].0.5 $\mathrm{ml}$ of $\mathrm{H}_{2} \mathrm{O}_{2}$ was added to $20 \mu \mathrm{l}$ of serum and incubated for $5 \mathrm{~min}$ at $37{ }^{\circ} \mathrm{C}$. Working reagent was added and immediately the absorbance of blank and sample were read against distilled water at $505 \mathrm{~nm}$.

The malondialdehyde level was calculated by the thiobarbituric acid reactive species (TBARS) technique. This method is based on the reaction of malondialdehyde and other aldehydes, which are by products of membrane damage caused by ROS, with thiobarbituric acid (TBA) at low $\mathrm{pH}$ and high temperature forming a complex with maximum light absorption at $535 \mathrm{~nm}$ [28]. One $\mathrm{ml}$ of TBA was added to $200 \mu \mathrm{l}$ of serum, mixed well in the test tube and boiled in $95{ }^{\circ} \mathrm{C}$ boiling water bath for $30 \mathrm{~min}$. The absorbance of sample against blank and standard against distilled water was read at $534 \mathrm{~nm}$.

Hydrogen peroxide was determined in the plasma by the reaction of $\mathrm{H}_{2} \mathrm{O}_{2}$ with 3, 5-dichloro-2-hydroxybenzensulfonic (DHBS) acid and 4-aminophenazone (AAP) in the presence of peroxidase (HRP) to form a chromophore. This method had been developed by Fossati et al. [29]. $500 \mu \mathrm{l}$ of DHBS and $500 \mu \mathrm{l}$ of AAP was added to $50 \mu$ of plasma in a glass tube, and incubated for $10 \mathrm{~min}$ at $37{ }^{\circ} \mathrm{C}$. The sample and standard were read against blank at $510 \mathrm{~nm}$.

Complete blood count was measured using automated analyzer (Sysmex). 
Table 1 Demographics and baseline characteristics

\begin{tabular}{|c|c|c|c|c|c|}
\hline Characteristics & Mean & SD & Median & Maximum & Minimum \\
\hline Age & 16.26 & 8.52 & 15 & 42 & 5 \\
\hline Gender & 23(49\%) Male & & & & \\
\hline Base line weight (Kg) & $35 \cdot 96$ & 14 & $37 \cdot 3$ & 63 & 13 \\
\hline Base line height $(\mathrm{Cm})$ & $148 \cdot 34$ & 20.99 & $154 \cdot 5$ & 107 & 190 \\
\hline $\mathrm{Hb} \mathrm{g} / \mathrm{dL}$ & 7.28 & 1.105 & 7 & 11 & $5 \cdot 5$ \\
\hline $\mathrm{Hb} F(\%)$ & 6.68 & 5.44 & 4.80 & 17.50 & 00 \\
\hline $\mathrm{Hb} S(\%)$ & $89 \cdot 99$ & $5 \cdot 15$ & 91 & $97 \cdot 20$ & $79 \cdot 40$ \\
\hline $\mathrm{HbA}_{2}(\%)$ & $3 \cdot 33$ & 0.52 & $3 \cdot 3$ & $4 \cdot 4$ & $2 \cdot 5$ \\
\hline TAC mmol/L & 0.32 & 0.077 & 0.33 & 0.50 & 0.17 \\
\hline MDA nmol/mL & 6.35 & 3.73 & 6.0 & 14.4 & 0.29 \\
\hline $\mathrm{H}_{2} \mathrm{O}_{2} \mathrm{mmol} / \mathrm{L}$ & 0.47 & 0.21 & 0.46 & 1.44 & 0.15 \\
\hline
\end{tabular}

Data were analyzed using SPSS version 20. Paired samples $\mathrm{T}$ test was used to compare between pre and post intervention results. Person correlation was used to find correlation between different parameters. $P$ values equal or less than 0.05 was considered significant.

\section{Results}

Forty seven patients were enrolled (Table 1). All were Sudanese; 23 were males, age 5 to 42 years. Duration of treatment was for 12 weeks except two patients received GA for nine weeks and eight patients for ten weeks. The last recorded results were considered for final analysis as post treatment results.

Oral Gum Arabic intake significantly increased the level of TAC (Fig. 1) and reduced the levels of both: MDA (Fig. 2) and $\mathrm{H}_{2} \mathrm{O}_{2}$ (Fig. 3). Response rate was $60 \%$. We observed significant positive correlation between base line TAC and hemoglobin (Fig. 4). We also found significant correlation between MDA level and TWBC count (Fig. 5). $\mathrm{H}_{2} \mathrm{O}_{2}$ level was positively correlated with MCV baseline level (Fig. 6).

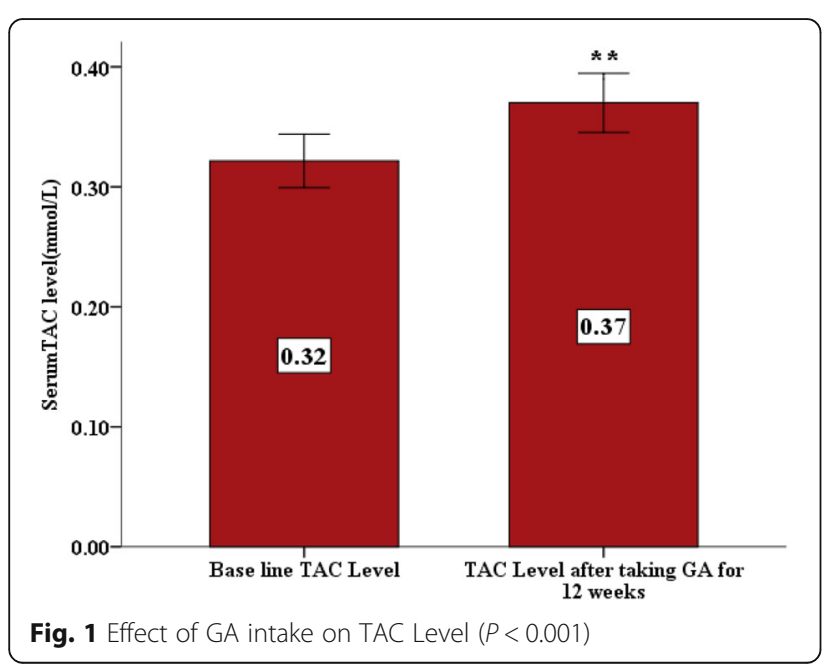

\section{Discussion}

Sickle cell anemia patients suffer from oxidative stress [7] which is caused by chronic inflammation [1] and self-oxidation of $\mathrm{Hb} \mathrm{S}$ [30]. Chronic oxidative stress contributes to endothelial dysfunction, inflammation and multiple organ damage in SCD [30]. Antioxidant enzymes were significantly less in red blood cells of SCA patients than in red blood cells of healthy controls [7]. Sickle erythrocytes have been shown to have elevated levels of ROS as compared to normal (AA) erythrocytes [1]. Chronic oxidative stress in SCD is caused by an imbalance between the production of reactive oxygen species (ROS) and antioxidant enzyme activity [8]

Agents that increase the antioxidant capacity of sickle patients were expected to improve their clinical condition [7]. Trials of antioxidant agents in mouse models of SCD also appear to reduce markers of acute and chronic inflammation [1].

In our study GA increased TAC of patients $(P<.0 .001)$. GA is known to have antioxidant properties, which have been illustrated in animal model of CRF [18, 31]. GA

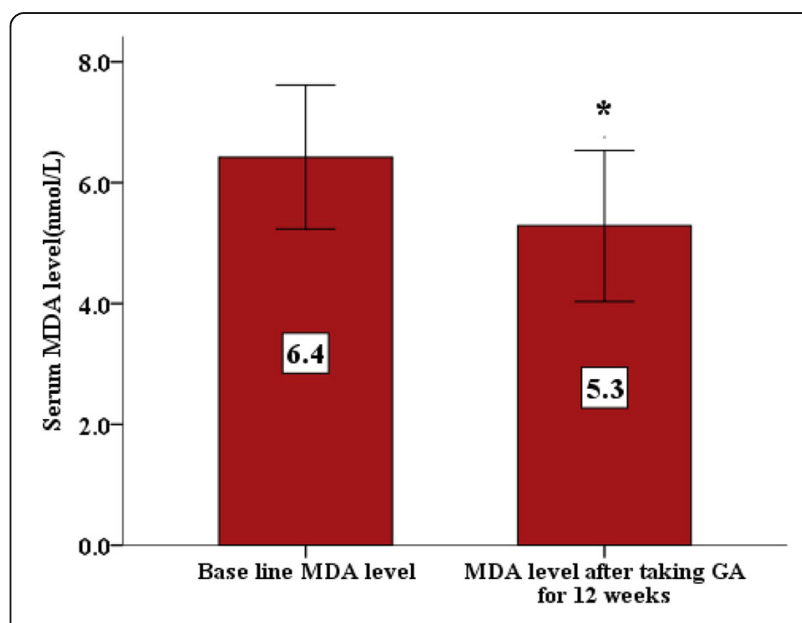

Fig. 2 Effect of GA intake on MDA Level $(P<0.05)$ 


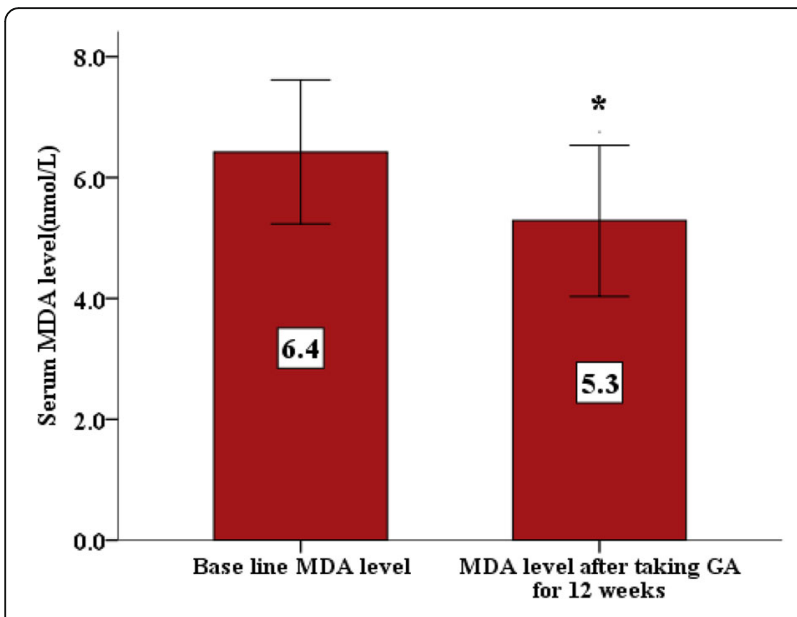

Fig. 3 Effect of $\mathrm{GA}$ intake on $\mathrm{H}_{2} \mathrm{O}_{2}$ Level $(P<0.005$

increased anti-oxidant enzymes like superoxide dismutase (SOD), catalase and glutathione [31]. GA microcapsules found to be potent anti-oxidant agent in vitro [23]. Our results confirmed that GA has anti-oxidative properties which can be utilized to improve patient's condition and attenuate disease severity.

Oxidative stress, which is manifested by a significant increase in the levels of MDA and inhibition of the peroxidase and catalase enzymes, presents a major cause of the tissue damage [16]. MDA, which is a byproduct of lipid peroxidation [7], is higher in SCA patients than healthy controls [7].

GA significantly decreased MDA levels in a chronic renal failure (CRF) animal model and nephrotoxicity $[25,31]$. In our study GA significantly decreased the MDA level (Fig. 2). This interesting result indicates that

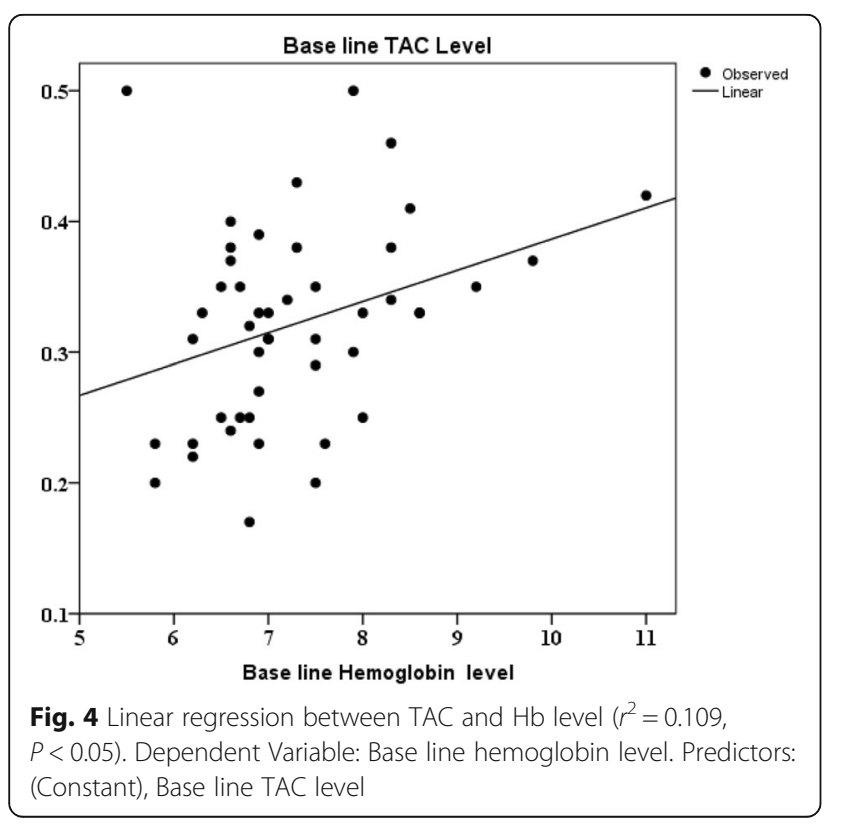

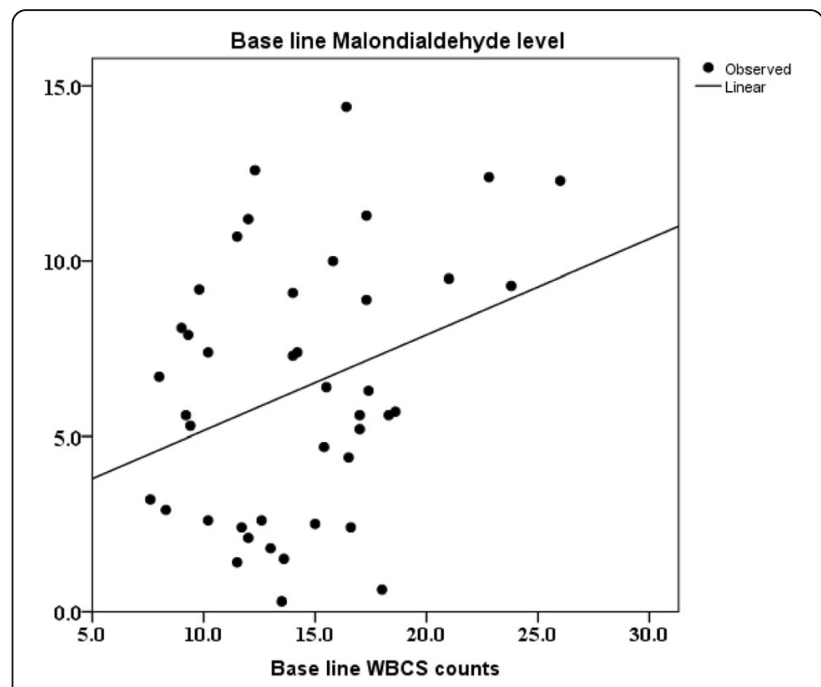

Fig. 5 Linear regression between MDA and WBCs count $\left(r^{2}=0.102\right.$, $P<0.05)$. Dependent Variable: Base line MDA level. Predictors:

(Constant), Base line WBCs level

GA may have protective effect against oxidative stress and tissue damage in these patients.

Hydrogen peroxide $\left(\mathrm{H}_{2} \mathrm{O}_{2}\right)$ was viewed as a toxic molecule to human tissues [32]. Sickle cell erythrocytes produce twice as much superoxide, $\mathrm{H}_{2} \mathrm{O}_{2}$ and hydroxyl radical as compared to normal healthy controls [10]. GA significantly decreased $\mathrm{H}_{2} \mathrm{O}_{2}$ level in SCA patients (Fig. 3). Several studies pointed to catalase as the primary enzyme responsible for protecting the red cell from $\mathrm{H}_{2} \mathrm{O}_{2}$ [33] GA increased catalase activity as evidenced in several animal models [31, 34]. GA also increases $\mathrm{H}_{2} \mathrm{O}_{2}$ scavenging capacity in vitro [23]. This may explain the decrease we have noticed in $\mathrm{H}_{2} \mathrm{O}_{2}$ level after taking GA for 12 weeks.

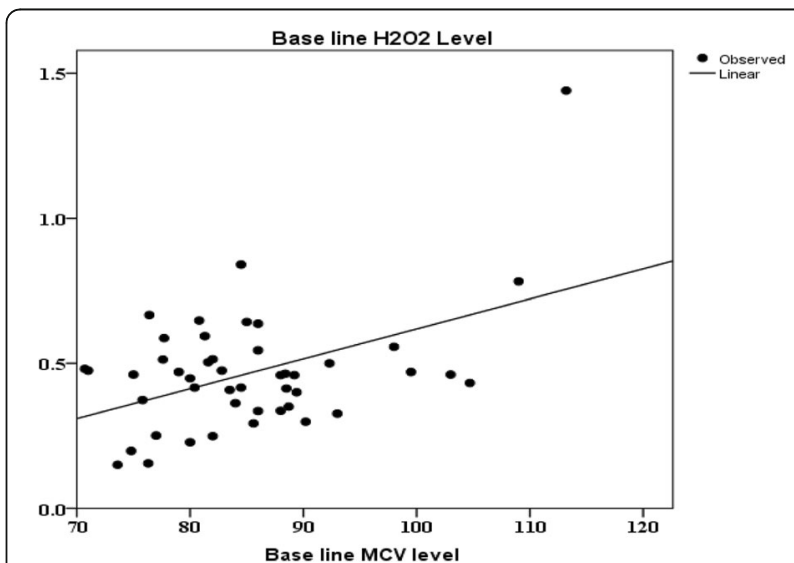

Fig. 6 Linear regression between $\mathrm{H}_{2} \mathrm{O}_{2}$ and MCV level $\left(r^{2}=0.219\right.$ $P=0.001)$. Dependent Variable: Base line $\mathrm{H}_{2} \mathrm{O}_{2}$ level. Predictors: (Constant), Base line MCV level 


\section{Conclusions}

Our results provided more evidence that GA has potent anti- oxidative effects in humans as demonstrated by its ability to increase TAC and to decrease oxidative stress markers in humans. All previous studies were conducted in animal models or in vitro studies. The present study thus uncovers a novel effect of GA which can be utilized in other clinical conditions and diseases caused by increased lipid peroxidation and tissue injury. Thus the increased intake of dietary antioxidants from GA may help to maintain an adequate antioxidant defense status and consequently contribute to the management of SCD.

\section{Abbreviations}

GA: Gum Arabic; $\mathrm{H}_{2} \mathrm{O}_{2}$ : Hydrogen peroxide; HbS: Sickle hemoglobin; MDA: Malondialdehyde; SCA: Sickle cell anemia; TAC: Total anti-oxidant

\section{Acknowledgement}

We would like to thank Dar Savanna Ltd. Khartoum, Sudan (www.darsavanna.net) for providing gum Arabic as gift for the study.

\section{Funding}

This research was funded by a grant from Higher Education and Scientific Research Ministry to AS. Supporting fund was also obtained from Alneelain University Khartoum Sudan to principal Investigator LK.

\section{Availability of data and materials}

All data generated or analyzed during this study are included in this published article.

\section{Authors' contributions}

LK, IF, FL and AS participated in study design. LK, IF and AS were involved in all aspects of the study conduct. LK, AS, IF, and FL participated in the writing and review of the manuscript. LK and AS analyzed data. LK and MS performed laboratory studies. OE and HE were significant clinical contributors to the study. All authors approved final version of manuscript.

\section{Competing interests}

The authors declare that they have no competing interests.

\section{Consent for publication}

Principal investigator obtained informed consent from each participant or from parents when the patient was less than 18 years to publish the data without breaching confidentiality.

\section{Ethics approval and consent to participate}

Ethical clearance was obtained from the Institutional Review Board at Alneelain University and from Research Ethics Committee- Khartoum State Ministry of Health. Principal investigator obtained written informed consent from each participant or from parents or legal guardians when the patient was less than 18 years prior to enrollment.

\section{Publisher's Note}

Springer Nature remains neutral with regard to jurisdictional claims in published maps and institutional affiliations.

\section{Author details}

${ }^{1}$ Department of Physiology, Faculty of Medicine, Alneelain University, P.O. Box: 11121, Khartoum 12702, Sudan. ${ }^{2}$ Alneelain Research Centre Faculty of Medicine, Alneelain University, Khartoum, Sudan. ${ }^{3}$ Department of Hematology Military Hospital, Khartoum, Sudan. ${ }^{4}$ Department of Pediatrics Military Hospital, Khartoum, Sudan. ${ }^{5}$ Department of Biochemistry, Faculty of Medicine, University of Khartoum, Khartoum, Sudan. ${ }^{6}$ Department of Physiology, University of Tübingen, Tübingen, Germany. ${ }^{7}$ Department of Physiology, Faculty of Medicine, University of Khartoum, Khartoum, Sudan.
Received: 25 October 2016 Accepted: 7 March 2017

Published online: 16 March 2017

\section{References}

1. George A, Pushkaran S, Konstantinidis DG, Koochaki S, Malik P, Mohandas N, et al. Erythrocyte NADPH oxidase activity modulated by Rac GTPases, PKC, and plasma cytokines contributes to oxidative stress in sickle cell disease. Blood. 2013;121(11):2099-107.

2. Bhagat S, Patra PK, Thakur AS. Association of inflammatory biomarker Creactive protein, lipid peroxidation and antioxidant capacity marker with $\mathrm{HbF}$ level in sickle cell disease patients from Chattisgarh. Indian J Clin Biochem. 2012;27(4):394-9.

3. Thakur AS, Littaru GP, Moesgaard S, Dan SC, Khan Y, Singh CM. Hematological parameters and RBC TBARS level of Q 10 supplemented tribal sickle cell patients: a hospital based study. Indian J Clin Biochem. 2013;28(2):185-8.

4. Fasola F, Adedapo K, Anetor J, Kuti M. Total antioxidants status and some hematological values in sickle cell disease patients in steady state. J Natl Med Assoc. 2007;99(8):891-4

5. Torres LS, da Silva DG, Belini JE, de Almeida EA, Lobo CL, Cancado RD, et al. The influence of hydroxyurea on oxidative stress in sickle cell anemia. Rev Bras Hematol Hemoter. 2012;34(6):421-5.

6. Chirico EN, Pialoux V. Role of oxidative stress in the pathogenesis of sickle cell disease. IUBMB Life. 2012;64(1):72-80.

7. Manfredini V, Lazzaretti LL, Griebeler IH, Santin AP, Brandao VD, Wagner S, et al. Blood antioxidant parameters in sickle cell anemia patients in steady state. J Natl Med Assoc. 2008;100(8):897-902.

8. Henneberg R, Otuki MF, Furman AE, Hermann P, do Nascimento AJ, Leonart MS. Protective effect of flavonoids against reactive oxygen species production in sickle cell anemia patients treated with hydroxyurea. Rev Bras Hematol Hemoter. 2013;35(1):52-5.

9. Hasanato RM. Zinc and antioxidant vitamin deficiency in patients with severe sickle cell anemia. Ann Saudi Med. 2006;26(1):17-21.

10. Titus J, Chari S, Gupta M, Parekh N. Pro-oxidant and anti-oxidant status in patients of sickle cell anaemia. Indian J Clin Biochem. 2004;19(2):168-72.

11. Essien EU. Plasma levels of retinol, ascorbic acid and alpha-tocopherol in sickle cell anaemia. Cent Afr J Med. 1995:41(2):48-50.

12. Nasir O. Renal and extrarenal effects of gum arabic (Acacia senegal)-what can be learned from animal experiments? Kidney Blood Press Res. 2013; 37(4-5):269-79.

13. Babiker R, Merghani TH, Elmusharaf K, Badi RM, Lang F, Saeed AM. Effects of Gum Arabic ingestion on body mass index and body fat percentage in healthy adult females: two-arm randomized, placebo controlled, doubleblind trial. Nutr J. 2012;11:111.

14. Ballal A, Bobbala D, Qadri SM, Foller M, Kempe D, Nasir O, et al. Anti-malarial effect of gum arabic. Malar J. 2011;10:139.

15. Ali BH, Al-Husseni I, Beegam S, Al-Shukaili A, Nemmar A, Schierling S, et al. Effect of gum arabic on oxidative stress and inflammation in adenineinduced chronic renal failure in rats. PLoS One. 2013;8(2):e55242.

16. Al-Yahya AA, Al-Majed AA, Gado AM, Daba MH, Al-Shabanah OA, Abd-Allah AR. Acacia Senegal gum exudate offers protection against cyclophosphamide-induced urinary bladder cytotoxicity. Oxid Med Cell Longev. 2009;2(4):207-13.

17. Ali BH, Al-Salam S, Al Za'abi M, Al Balushi KA, Ramkumar A, Waly MI, et al. Does swimming exercise affect experimental chronic kidney disease in rats treated with gum acacia? PLoS One. 2014;9(7):e102528.

18. Ali BH, Beegam S, Al Lawati I, Waly MI, Nemmar A. Comparative efficacy of three brands of gum arabic on adenine-induced chronic renal failure in rats. Physiol Res. 2013:62(1):47-56.

19. Ali BH, Ziada A, Blunden G. Biological effects of gum arabic: a review of some recent research. Food Chem Toxicol. 2009:47(1):1-8.

20. Ali BH, Ziada A, Al Husseni I, Beegam S, Al-Ruqaishi B, Nemmar A. Effect of Acacia gum on blood pressure in rats with adenine-induced chronic renal failure. Phytomedicine. 2011;18(13):1176-80.

21. Ali BH, Al-Salam S, Al Za'abi M, Waly MI, Ramkumar A, Beegam S, et al. New model for adenine-induced chronic renal failure in mice, and the effect of gum acacia treatment thereon: comparison with rats. J Pharmacol Toxicol Methods. 2013;68(3):384-93.

22. Ali BH, Al-Salam S, Al Husseni I, Kayed RR, Al-Masroori N, Al-Harthi T, et al. Effects of Gum Arabic in rats with adenine-induced chronic renal failure. Exp Biol Med (Maywood). 2010;235(3):373-82. 
23. Rodrigues E, Mariutti LR, Faria AF, Mercadante AZ. Microcapsules containing antioxidant molecules as scavengers of reactive oxygen and nitrogen species. Food Chem. 2012;134(2):704-11.

24. AbdГÇÉAllah AR, AlГÇÉMajed AA, Mostafa AM, AlГÇÉShabanah OA, Din AGE, Nagi MN. Protective effect of arabic gum against cardiotoxicity induced by doxorubicin in mice: a possible mechanism of protection. J Biochem Mol Toxicol. 2002;16(5):254-9.

25. Al-Majed AA, Abd-Allah AR, Al-Rikabi AC, Al-Shabanah OA, Mostafa AM. Effect of oral administration of Arabic gum on cisplatin-induced nephrotoxicity in rats. J Biochem Mol Toxicol. 2003;17(3):146-53.

26. Nasir O, Umbach AT, Rexhepaj R, Ackermann TF, Bhandaru M, Ebrahim A, et al. Effects of gum arabic (Acacia senegal) on renal function in diabetic mice. Kidney Blood Press Res. 2012;35(5):365-72.

27. Koracevic D, Koracevic G, Djordjevic V, Andrejevic S, Cosic V. Method for the measurement of antioxidant activity in human fluids. J Clin Pathol. 2001; 54(5):356-61.

28. Satoh K. Serum lipid peroxide in cerebrovascular disorders determined by a new colorimetric method. Clin Chim Acta. 1978;90(1):37-43.

29. Fossati P, Prencipe L, Berti G. Enzymic creatinine assay: a new colorimetric method based on hydrogen peroxide measurement. Clin Chem. 1983;29(8): 1494-6.

30. Elias DB, Rocha LB, Cavalcante MB, Pedrosa AM, Justino IC, Goncalves RP. Correlation of low levels of nitrite and high levels of fetal hemoglobin in patients with sickle cell disease at baseline. Rev Bras Hematol Hemoter. 2012;34(4):265-9.

31. Mahmoud MF, Diaai AA, Ahmed F. Evaluation of the efficacy of ginger, Arabic gum, and Boswellia in acute and chronic renal failure. Ren Fail. 2012; 34(1):73-82.

32. Armogida M, Nistico R, Mercuri NB. Therapeutic potential of targeting hydrogen peroxide metabolism in the treatment of brain ischaemia. Br J Pharmacol. 2012;166(4):1211-24.

33. Nagababu E, Chrest FJ, Rifkind JM. Hydrogen-peroxide-induced heme degradation in red blood cells: the protective roles of catalase and glutathione peroxidase. Biochim Biophys Acta. 2003;1620(1-3):211-7.

34. Gado AM, Aldahmash BA. Antioxidant effect of Arabic gum against mercuric chloride-induced nephrotoxicity. Drug Des Devel Ther. 2013;7:1245-52.

\section{Submit your next manuscript to BioMed Central and we will help you at every step:}

- We accept pre-submission inquiries

- Our selector tool helps you to find the most relevant journal

- We provide round the clock customer support

- Convenient online submission

- Thorough peer review

- Inclusion in PubMed and all major indexing services

- Maximum visibility for your research

Submit your manuscript at www.biomedcentral.com/submit 